\title{
FORMATION AND DEVELOPMENT OF ADULT EDUCATION IN UKRAINE AND SLOVAK REPUBLIC: COMPARATIVE ANALYSIS
}

\author{
Oksana Samoilenko, \\ Doctoral student of department of pedagogy of Zhytomyr Ivan Franko State University \\ http://orcid.org/0000-0002-2305-4111 \\ e-mail: samoilenckooxana@gmail.com
}

\begin{abstract}
The article presents the results of the comparative analysis of the formation and development of adult education in Ukraine and the Slovak Republic. The general (globalization, democratization, individualization of adult education, and other) and specific (establishment of the legal framework, the introduction of an andragogical model of education in formal education institutions, and other) trends in the development of adult education in both countries.

It has been proved that the Slovak Republic as a member state of the European Union has a well-established tradition of adult education through legislative provision, an effective system of preparation of andragogues as adults in adult education, and didactic provision of adult education in formal and non-formal education institutions. In particular, the actual direction of using Slovak experience in the development of adult education in Ukraine is to promote the continuous professional development of adults through the advisory mechanism (poradenstvo) - personalized professional counseling. The analysis of the specialties that is training the personnel in the field of adult education in Ukraine has shown that andragogical counseling is tangent to such specialties as information management; management of personnel, organizations, socio-cultural activities, management of public organizations, public institutions, international educational projects, innovations in education, psychological counseling, etc. However, in Ukraine, unlike Slovakia, it does not have a clear focus on the andragogical aspect of counseling, but it has a clear focus on management. This makes it impossible for an interdisciplinary approach to the counseling system that we see it in the Slovak Republic, with a clear distinction between the andragogical context.
\end{abstract}

Keywords: adult education, andragogical approach, andragogue, counseling.

Introduction.Ukraine on the world map appears quite young and promising in its development by the state, the success of which is partly dependent on the productive extrapolation of foreign experience in the formation of effective social relations, in particular in the field of adult education. Following M. Borysova (2012, s.5), we believe that "the kingdom of adult education should take into account the specificity of the Ukrainian mentality, which is a given in the course of long development of national history and culture, and modern world experience". Therefore, it would be advisable to borrow certain assets in this field that work effectively in the education system of adult European Union countries, in particular the Slovak Republic.
Materials and methods. The problem of improving the adult education system in Ukraine with the use of progressive ideas of foreign experience is quite well represented in scientific pedagogical thought, in particular through coverage of the possibilities of applying the effective practices of Scandinavian (O.Ohiienko, A.Roliak) and Englishspeaking countries (N.Avsheniuk, T.Hryhorieva, S. Kovalenko), the USA and the Latin American countries (O.Zhyzhko, N. Kutova, N.Mukan, N.Terokhina, N.Chahrak), Canada (M.Borysova, M. Busko, L.Nos), Poland (O.Alpern, O.Serhieieva), France (O.Komar, V. Lashchykhina, Yu.Nesin), Germany (I. Sahun), Italian Republic (N. Postryhach, O.Chebotarova), Greece (O.Protsenko), China 
(N.Paziura), Australia and New Zealand (O.Pulinets). Significant achievements of domestic scientists make it possible to carry out a comparative analysis of the peculiarities of the development of adult education in Ukraine in the Slovak context.

Methods of research: terminological analysis, which made it possible to study the terminology apparatus of the study; systematization and comparison of normative, educational and methodical literature, which made it possible to find out the peculiarities of genesis of adult education in Ukraine and Slovakia

The purpose of the study is to make a comparative analysis of the formation and development of adult education in Ukraine and Slovakia.

Results and discussions. In the course of our study, a comparative analysis (Table 1) of the formation and development of adult education in Ukraine and Slovakia was carried out according to the following criteria: the existence of a national and regional adult education strategy; the legislative provision of adult education, the creation of organizational and pedagogical bases of lifelong learning, the development of a legal and regulatory framework for the training of pedagogical staff in the field of adult education, the availability of an effective system for the implementation of adult education, the possibility of validation and certification of the results of nonformal and informal education of adults.

Accordingly, the purpose of the study is to make a comparative analysis of the formation and development of adult education in Ukraine and Slovakia.

This made it possible to consider the development of adult education in Ukraine on the macro (level of society), meso- (level of organizations) and micro levels (level of personality).

A comparative study of the peculiarities of the development of adult education in Ukraine and the Slovak Republic provides grounds for arguing that in our country there is a process of actualization of this problem on the basis of the dissemination of European educational policy.

Currently, in pedagogical science, the term "dissemination" is interpreted as a special way of disseminating and mastering an experience that is adequate to the specific needs of its recipients, which has the character of formation. E. Chernyshova (2009) believes that dissemination allows dissemination of advanced and innovative experience in the most massive practice of leadership, scientific and pedagogical and pedagogical workers.

In this connection, the signing of the Association Agreement with the EU, which opened the space for opportunities for Ukraine to the powerful development of adult education. In particular, this is confirmed by
Art. 433 Agreements: "The Parties are studying the possibilities of developing cooperation in other spheres, in particular in the field of secondary education, distance education and life-long learning" (Угода про асоціацію з СС, 2015). The elaboration of previous years (the development of the Concepts of the Development of Distance Education in Ukraine (2000), the development of adult education in Ukraine (Сігаєва, 2009) and the Conceptual Provisions of the Education of Adults in Ukraine made it possible to amend the Law of Ukraine " About Education "(Article 18. Education of Adults) and the public discussion of the draft Law of Ukraine" About Adult Education".

In particular, it is legally stipulated that "adult education, which is a component of life-long education, is aimed at implementing the right of every adult to continuous education, taking into account his personal needs, priorities of social development and the needs of the economy" (Law of Ukraine "On Education").

The components of adult education include: postgraduate education; professional training of employees; retraining and / or advanced training courses; continuous professional development; any other components stipulated by the legislation proposed by the subject of educational activity or independently determined by the person.

A person has the right of free choice of educational institution, institution, organization, other subject of educational activity, types, forms, rate of education and educational program within the framework of adult education.

Postgraduate education involves acquiring new and improving competences previously acquired on the basis of the acquired higher professional (vocational) or professional advanced education and practical experience through:

- specialization - specialized training for the purpose of acquiring a person's ability to perform tasks and duties that have special features within the specialty;

- retraining - adult education aimed at vocational training with the aim of mastering another (other) profession;

- advanced training - the person acquiring new and / or improving previously acquired competencies within the professional activity or field of knowledge;

- Internship - acquiring a person's practical experience in the performance of tasks and responsibilities in a particular professional activity or field of knowledge.

Public authorities and local self-government bodies create conditions for formal, non-formal and informal education of adults, in particular through the public system (Ukrainian Association for the Education of Adults, public organizations of various levels in the 
Table 1

Comparative analysis of the peculiarities of adult education development in Ukraine and in the Slovak Republic

\begin{tabular}{|c|c|c|c|}
\hline Level & Criteria & Slovak Republic & Ukraine \\
\hline \multirow{3}{*}{ 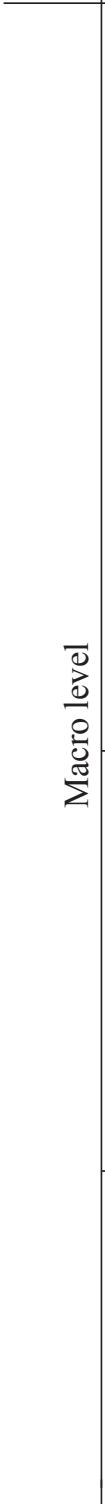 } & $\begin{array}{l}\text { availability of national } \\
\text { and regional } \\
\text { adult education strategy }\end{array}$ & $\begin{array}{l}\text { - National document of the Slovak } \\
\text { Republic to the Memorandum on } \\
\text { Continuing Education (2001) } \\
\text { - Concept of education during the life } \\
\text { of SR (2004) } \\
\text { - Strategy for education during life } \\
\text { and counseling } \\
\text { - National ESF project "Establishing, } \\
\text { developing and implementing } \\
\text { a lifelong education system for labor } \\
\text { market needs" (2007) } \\
\text { - Strategy for life-long learning - } 2011 \\
\text { - Program for the promotion of the } \\
\text { concept of education throughout } \\
\text { life (2011) }\end{array}$ & $\begin{array}{l}\text {-Association Agreement between } \\
\text { Ukraine, on the one hand, and the } \\
\text { European Union, the European Atomic } \\
\text { Energy Community and their member } \\
\text { states, on the other. Article } 433 \\
\text { - Concept of development of distance } \\
\text { education in Ukraine (2000) } \\
\text { - development of "Concept of adult } \\
\text { education development in Ukraine" } \\
\text { (author L. Sihaieva) } \\
\text { - presentation by the group of scientists } \\
\text { of the Institute of Pedagogical } \\
\text { Education and Adult Education of } \\
\text { the Academy of Pedagogical Sciences } \\
\text { (leader of the group - L. B. Lukianova). } \\
\text { of the draft Conceptual Provisions on } \\
\text { the Education of Adults in Ukraine } \\
\text { in March } 2009 \text {. }\end{array}$ \\
\hline & $\begin{array}{l}\text { legislative provision of adult } \\
\text { education, creation } \\
\text { of organizational } \\
\text { and pedagogical bases } \\
\text { for lifelong learning }\end{array}$ & $\begin{array}{l}\text { - Law 386/1997 Z. z. "About Further } \\
\text { Education" } \\
\text { - Act 282/2008 Z. z. "On the Basic } \\
\text { Principles of Youth Policy" and the } \\
\text { corresponding amendments to the } \\
\text { Laws "About Higher Education" } \\
\text { 131/2002 Z. et al. } \\
\text { - Law 568/2009 Z. z. "About life-long } \\
\text { education" and changes to others. } \\
\text { (2009) }\end{array}$ & $\begin{array}{l}\text { - Law of Ukraine "About Education" } \\
\text { Art. 18. Adult education } \\
\text { - public discussion of the draft Law } \\
\text { of Ukraine "About Adult Education" }\end{array}$ \\
\hline & $\begin{array}{l}\text { elaboration of the legal } \\
\text { and regulatory framework } \\
\text { for training pedagogical } \\
\text { staff in the field of adult } \\
\text { education }\end{array}$ & $\begin{array}{l}\text { - Law 568/2009 Z. z. "About life-long } \\
\text { education" and changes to others. } \\
\text { (2009) } \\
\text { - Law 386/1997 Z. z. "About Further } \\
\text { Education" } \\
\text { - Lifelong Education and Certification } \\
\text { Program for Education throughout } \\
\text { Life (2011) }\end{array}$ & $\begin{array}{l}\text { Project of Change No. } 8 \text { to the } \\
\text { the profession "Andragogue") } \\
\text { Classifier of Professions entrusted } \\
\text { with Code } 2359.2\end{array}$ \\
\hline 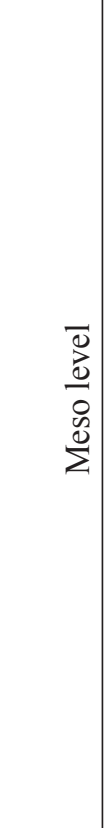 & $\begin{array}{l}\text { the existence of an effective } \\
\text { system for implementing } \\
\text { adult education }\end{array}$ & $\begin{array}{l}\text { The adult education system is represented } \\
\text { by the public activities (Association of Adult } \\
\text { Education Institutions in the Slovak Republic } \\
\text { (AIVD SR), the Association of Third-Level } \\
\text { Universities (ASUTV), the Association of } \\
\text { Career Coaches and Consultants (ALKP), } \\
\text { the Association of Employers and } \\
\text { Professional Organizations of the Slovak } \\
\text { Republic (AZZZ SR ), The Platform for } \\
\text { Non-Governmental Development } \\
\text { Organizations (MVRO), the Slovak } \\
\text { Employers' Association (RUZ), the Slovak } \\
\text { Academic Lifelong Learning Association } \\
\text { (SAACV), the Slovak Academic } \\
\text { Association for International Cooperation } \\
\text { (SAAIC), the Association Career } \\
\text { Development and Advisory (ZPKPRK) } \\
\text { and State (State Institute for Vocational } \\
\text { Education (SAAIC), National Agency } \\
\text { Erasmus +) organizations. }\end{array}$ & $\begin{array}{l}\text { The adult education system is } \\
\text { represented by the public activities } \\
\text { (Ukrainian Association for the } \\
\text { Education of Adults, public } \\
\text { organizations of various levels in the } \\
\text { field of cultural and educational } \\
\text { development), and state organizations } \\
\text { (Institute of Pedagogical Education and } \\
\text { Adult Education of the National } \\
\text { Academy of Pedagogical Sciences of } \\
\text { Ukraine, National Agency Erasmus }+ \text { ) } \\
\text { of organizations. }\end{array}$ \\
\hline
\end{tabular}


Continuation of Table 1

Comparative analysis of the peculiarities of adult education development in Ukraine and in the Slovak Republic

\begin{tabular}{c|cll} 
Level & Criteria & Slovak Republic & Ukraine \\
\hline & $\begin{array}{c}\text { the possibility of validation } \\
\text { and certification of the } \\
\text { results of non-formal } \\
\text { and informal education } \\
\text { of adults }\end{array}$ & $\begin{array}{l}\text { Qualification System KOPLAT } \\
\text { Professional } \\
\text { development of workers "(2012); } \\
\end{array}$ & $\begin{array}{l}\text { Law of Ukraine "About Education" } \\
\text { - Methodological recommendations } \\
\text { on the criteria for evaluating } \\
\text { professional knowledge, skills and }\end{array}$ \\
& $\begin{array}{l}\text { abilities, the list of tools for measuring } \\
\text { professional knowledge, skills and } \\
\end{array}$ & $\begin{array}{l}\text { competences based on the results } \\
\text { of non-formal vocational training } \\
\end{array}$ & (2015)
\end{tabular}

cultural and educational direction), and state institutions (Institute of Pedagogical Education and Adult Education of the National Academy of Pedagogical Sciences of Ukraine, National Agency Erasmus + ) organizations.

Undoubtedly, the introduction to the Classifier of Professions of the specialty "Andargogue" (2018) is a powerful factor for the adoption of the Law "About the Education of Adults", which will form the basis for the formation of a scientific and methodological basis for the training of adults in adult education in Ukraine. In this context, the experience of the Slovak Republic for the national pedagogical practice is exemplary.

Another important trend in the use of Slovak experience in the development of adult education in Ukraine is the promotion of continuous professional development of adults through the advisory mechanism (poradenstvo) - personalized professional counseling. The term "poradenstvo" comes from the English word "to consult" - and means "(po) radit' (sa)" - to counsel, prompt, offer, admit, advise.

The functioning of an effective counseling system in Slovakia is provided by the Life Long Life Concept (2008), the Life Long Learning Strategy (2007) and Lifelong Life Advice (2007) and the Career Development and Advisory Association (ZPKPRK).

The concept of lifelong counseling defines counseling as a continuous process that helps adults shape skills, competences and interests, make decisions about education, training / retraining and employment, and build an individual development strategy in education, work and other areas of life where these skills and competences can be acquired and / or used.

The Life Strategy and Life Advice Strategy (2007) states that "counseling is a set of counseling services provided to adults in accordance with their inquiries to address education, career choices and career development at any stage of their life.
The program of the development of the Slovak Republic (2008) proclaims the need to create the necessary conditions for the introduction of a system of counseling in order to create equal opportunities for citizens to receive information not so much about the potential of adult education, but also about the prospects of applying the acquired knowledge, skills in the labor market, which will enable to properly direct adults in choosing the forms of study, will increase their ability to work and mobility in the labor market.

Slovak scholar L. Hloushkova (Hloušková, 2010) states that "counseling carries out a supporting function in life-long education, providing for the formation of individual competences for the management and planning of their professional growth and education. The scientist recognizes the two-sidedness of this process: life-long counseling through education will contribute to the overall development of an adult's personality. L. Shirova adds that "the concept of counseling should help adults to solve a number of important issues" (Š́rová, 2010).

C. Mayer defines counseling as a systemic institution, a professional and comprehensive service whose purpose is to provide advice, information, and solutions in solving specific life problems (Mayer, 2017). We are talking about a specially organized professional orientation of the individual based on an analysis of its relevance, taking into account the physical and psychological individual characteristics, general and professional interests, inclinations and abilities, the level of education and training. In conducting the consultation also take into account the needs of the labor market, employment opportunities, professional growth, working conditions, etc. The author notes the close interaction between life-long education and counseling, which serves as a facilitator of lifelong learning, whose effectiveness is determined by the quality of the counseling process. 
I. Pirohova implies such counseling as an andragogy - a specific form of assistance to an adult in problem situations through education and training (Pirohová, 2015). The psychological sense of counseling is to help adults resolve their own problems of professional life. Hence the main task of counseling is to reconcile the individual professional capabilities and needs of the client with the interests of the labor market, as a result of which professional selfdetermination of the individual takes place, her life and professional plans are formed or perfected, and productive changes are made in her professional activity and behavior.

The subject of andragogical counseling is defined by V. Prusakova as (Prušaková, 2005):

$\checkmark$ problem situations that can be solved through education and training, such as unemployment, career growth, career change, etc. Customers seek help from a consultant to assist in solving the situation, obtaining reliable information on the labor market and its needs;

$\checkmark$ the issue of the effective use of leisure time (leisure), in particular by means of training;

$\checkmark$ problems arising in the training of both the adult and the person who teaches them about the forms, methods, techniques and teaching techniques. For example, an adult does not know how to build his own learning strategy, how to combine work and education, where to get the appropriate education, etc. The consultant, along with the adult, makes an individual training schedule for the adult and helps in its implementation. On the other hand, in andragogy also there may be problems as to which techniques can be effective in adult learning. In this case, the counselor helps the andragogue in the selection of effective techniques.

Considering the subject of andragogical counseling, C. Mayer highlights two types of counseling professional and career, which differ in the following: the first occurs predominantly at the beginning of the adult work and provides him with awareness of the professional orientations of the individual. Career guidance is effective if you meet the need for an adult career growth, when you select a career strategy advancement strategy. Such a division of andragogical counseling is due to the dynamic development of continuing education, the emergence of the need for education in life, the constant changes in the labor market in accordance with the economic transformation of society and the need for the acquisition of modern competencies by adults.

The subject "Andragogical advice" is obligatory for the students of the third year of bachelor's degree studying in the specialty "Andragogy" at the universities of Slovakia, in particular, at University of Prešov. Contents of the discipline are: the history of the development of andragogical counseling; scientific concepts of andragogical counseling; approaches to andragogical counseling and its types; the specifics of the consultation process and its stages; methodology of andragogical counseling; professional ethics and counseling (andragogický poradca); Emotional burnout syndrome and its prevention.

The analysis of the specialties that is training the personnel in the field of adult education in Ukraine has shown that andragogical counseling is tangent to such specialties as information management; management of personnel, organizations, sociocultural activities, management of public organizations, public institutions, international educational projects, innovations in education, psychological counseling, etc. However, in Ukraine, unlike Slovakia, it does not have a clear focus on the andragogical aspect of counseling, but it has a clear focus on management. This makes it impossible for an interdisciplinary approach to the counseling system that we see it in the Slovak Republic, with a clear distinction between the andragogical context.

Conclusion. The presented analysis of trends in the development of adult education provides grounds for identifying a common and characteristic process for this process in Ukraine and in Slovakia. Thus, the general tendencies are: globalization, democratization, individualization of adult education, alternative ways of obtaining education, orientation of professional training of adults in adult education to ensure the competitiveness of the adult in the labor market.

Specific features of the development of adult education in Ukraine are: the establishment of a legal and regulatory framework; the introduction of an andragogical model of training in formal education institutions, professional training of andragogues as a separate area for the training of adults in adult education, and initiatives to create and disseminate the experience of creating innovative educational services for different categories of adult population.

The Slovak Republic as a member state of the European Union has a well-established tradition of adult education through legislative provision, an effective system of training andragogues as adults in adult education, and providing adult education in formal and non-formal education institutions. Ukraine is just beginning to climb on the path to the formation of an adult education system as a powerful sphere of social and economic development of the country. And the first step in this direction should be the adoption of the Law "About the Education of Adults", the project of which received serious support from the public.

The perspectives of further research include the analysis of the peculiarities of training specialists in the field of adult education in the Slovak Republic with the possibility of transferring positive European experience to the domestic educational practice of higher education institutions. 


\section{List of references}

Борисова. М. В., 2012. Розвиток освіти дорослих у Канаді: автореферат. Кандидат наук. Черкаський національний університет ім. Богдана Хмельницького, Черкаси.

Законодавство України, 2015. Угода про асоціацію між Україною, з однісї сторони, та європейським союзом, європейським співтовариством з атомної енергії і їхніми державами-членами, з іншої сторони. [online] (Останнє оновлення 01 Вересень 2017) Доступно: <https://zakon.rada.gov.ua/laws/show/984_011> [Дата звернення 03 Травень 2018].

Сігаєва, Л. Є., 2009. Концуепиія розвитку освіти дорослих в Украӥні. Київ: ЕКМО.

Чернишова, Є., 2009. Десимінація інноваційного досвіду науково-методичної діяльності навчальних закладів післядипломної педагогічної освіти. Теорія та методика управління освітою, [online] 2. Доступно: <http:// tme.umo.edu.ua/docs/2/1.pdf> [Дата звернення 08 Квітень 2019].

Asociácia lektorov a kariérnych poradcov, 2007. [online] Stratégia celoživotného vzdelávania a celoživotného poradenstva. Доступно: https://alkp.sk/wp-content/uploads/2016/05/Stratégia-celoživotného-vzdelávania-aceloživotného-poradenstva.pdf [Дата звернення 08 Квітень 2019].

Hloušková, L., 2010. Celoživotní poradenství jako prúležitost pro dospělé. E-pedagogium. Nezávislý odborný časopis určený pedagogickým pracovníkiom vsech typů škol. Mimorádné čislo, 1, s. 11-22.

Mayer, K., 2017. Poradenstvo v andragogickom kontexte. Prešov: FF PU.

Ministerstvo školstva, vedy, výskumu a športu SR, 2008. [online] Modernizačný program Slovensko 21. Доступно: https://www.minedu.sk/data/att/2337.pdf [Дата звернення 08 Квітень 2019].

Ministerstvo školstva, vedy, výskumu a športu SR, 2017. [online] Memorandum o celoživotnom vzdelávani. Доступно: https://www.minedu.sk/data/files/2607_2000_memorandum_o_celozivotnom_vzdelavani.pdf [Дата звернення 07 Квітень 2018].

Pirohová, I., 2015. Teorie vzdelávania dospelých. Prešov: Prešovska univeryita v Prešove. Fakulta humanitných a prirodných vied.

Průsaková, V., 2005. Základy andragogiky I. Bratislava: Gerlach Print.

Sírová, L., 2010. Poradenstvo ako nástroj rozvoja človeka v službách pre dospelých. E-pedagogium. Nezávislý odborný časopis určený pedagogickým pracovníkưm všech typů škol, 1. mimorádné císlo, s. 11-22.

\section{Translated \& Transliterated}

Borysova, M. V., 2012 Rozvytok osvity doroslykh u Kanadi [Development of adult education in Canada]: avtoreferat. Kandydat nauk. Cherkasy National University named after Bogdan Khmelnitsky, Cherkasy, [in Ukrainian].

Zakonodavstvo Ukrainy [Legislation of Ukraine], 2015. [online] Uhoda pro asotsiatsiiu mizh Ukrainoiu, z odniiei storony, ta yevropeiskym soiuzom, yevropeiskym spivtovarystvom z atomnoi enerhii i yikhnimy derzhavamy-chlenamy, $z$ inshoi storony [Association Agreement between Ukraine, on the one hand, and the European Union, the European Atomic Energy Community and their Member States, on the other hand]. (Ostannie onovlennia 01 Veresen 2017) Dostupno:<https://zakon.rada.gov.ua/laws/show/984_011> [Data zvernennia 03 Traven 2018], [in Ukrainian].

Sihaieva, L. Ye., 2009. Kontseptsiia rozvytku osvity doroslykh v Ukraini [Concept of development of adult education in Ukraine]. Kyiv: ECMO, [in Ukrainian].

Chernyshova, Ye., 2009. Desyminatsiia innovatsiinoho dosvidu naukovo-metodychnoi diialnosti navchalnykh zakladiv pisliadyplomnoi pedahohichnoi osvity [Dissemination of innovative experience in scientific and methodological activity of educational institutions of postgraduate pedagogical education]. Teoriia ta metodyka upravlinnia osvitoiu [Theory and methodology of education management], [online] Dostupno: $<$ http://tme.umo.edu.ua/docs/2/1.pdf $>$ (Data zvernennia 08 Kviten 2019), [in Ukrainian].

Asociácia lektorov a kariérnych poradcov [Association of Lecturers and Career Advisors], 2007. Stratégia celoživotného vzdelávania a celoživotného poradenstva [Lifelong learning strategy and lifelong guidance]. [online] Available at: $<$ https:/ /alkp.sk/wp-content/uploads/2016/05/Stratégia-celoživotneho-vzdelávania-a-celoživotného-poradenstva.pdf $>$ [Accessed 08 Kviten 2019], [in Slovak].

Hloušková, L., 2010. Celoživotní poradenství jako príležitost pro došpelé [Lifelong guidance as an opportunity for adults]. E-pedagogium. Nezávislý odborný časopis určený pedagogickým pracovníkủm v́sech typů škol [E-pedagogium. An independent professional magazine for teachers of all types of schools. Extraordinary number], 1, p. 11-22, [in Slovak].

Mayer, K., 2017. Poradenstvo v andragogickom kontexte [Counseling in andragogic context]. Prešov: FF PU, [in Slovak].

Ministerstvo školstva, vedy, výskumu a športu SR [Ministry of Education, Science, Research and Sport of the Slovak Republic], 2017, [in Slovak].

Memorandum o celoživotnom vzdelávaní [Memorandum on lifelong learning], 2017. [online] Available at: https:// www.minedu.sk/data/files/2607_2000_memorandum_o_celozivotnom_vzdelavani.pdf (Accessed 07 Kviten 2018), [in Slovak].

Ministerstvo školstva, vedy, výskumu a športu SR [Ministry of Education, Science, Research and Sport of the Slovak Republic.], 2008. Modernizacný program Slovensko 21 [Modernization Program Slovakia 21]. [online] Available at: https://www.minedu.sk/data/att/2337.pdf [Accessed 08 Kviten 2019], [in Slovak].

Pirohová, I., 2015. Teorie vydelávania dospelých [Theory of Adult Education]. Prešov: Prešovska univerzita v Prešove. Fakulta humanitných a prírodných vied, [in Slovak]. 
Průsaková, V., 2005. Základy andragogiky I [Fundamentals of Andragogy I]. Bratislava: Gerlach Print, [in Slovak].

Sírová, L., 2010. Poradenstvo ako nástroj rozvoja človeka v službách pre dospelých [Counseling as a tool for human development in adult services]. E-pedagogium. Nezávislý odborný časopis urcený pedagogickým pracovníkủm všech typư škol. Mimořádné č́slo [E-pedagogium. An independent professional magazine for teachers of all types of schools. Extraordinary number], 1, p. 11-22, [in Slovak].

УДК 374.7-027.1(437.6)(477)

\section{Становлення та розвиток освіти дорослих в Україні та Словацькій республіці: порівняльний аналіз}

\section{Оксана Самойленко,}

докторант кафедри педагогіки Житомирського державного університету імені Івана Франка

Реферат. Представлено результати порівняльного аналізу становлення та розвитку освіти дорослих в Україні та Словацькій республіці. Визначено тенденції розвитку освіти дорослих у обох країнах: загальні (глобалізація, демократизація, індивідуалізація навчання дорослих, спрямованість професійної підготовки фахівців у галузі освіти дорослих на забезпечення конкурентоспроможності дорослого на ринку праці та ін.) та специфічні (становлення нормативно-правової бази, професійної підготовки андрагогів як окремого напряму підготовки фахівців у галузі освіти дорослих та ін.).

Доведено, що Словацька республіка як країна-член Свропейського Союзу має вже усталену традицію функціонування освіти дорослих через якісне законодавство, ефективну систему підготовки андрагогів як спеціалістів у галузі освіти дорослих, дидактичне забезпечення навчання дорослих у закладах формальної та неформальної освіти. Зокрема, актуальним напрямом використання словацького досвіду у розвитку освіти дорослих в Україні є сприяння безперервному професійному вдосконаленню дорослих через механізм порадництва (poradenstvo) - персонально орієнтованого професійного консультування. Аналіз спеціальностей, за якими ведеться підготовка персоналу в галузі освіти дорослих в Україні, показав, що андрагогічне порадництво дотичне до таких спеціальностей, як інформаційний менеджмент; менеджмент персоналу, організацій, соціокультурної діяльності, управління громадськими організаціями, закладами освіти, міжнародними освітніми проектами, інноваціями в освіті, психологічне консультування та ін. Утім в Україні, на відміну від Словаччини, воно не має чіткої спрямованості на андрагогічний аспект консультування, проте має чітку направленість на менеджмент. Це унеможливлює інтердисциплінарний підхід до системи порадництва, яким ми бачимо у Словацькій республіці, 3 чітким виділенням андрагогічного контексту.

Ключові слова: освіта дорослих, андрагогічний підхід, андрагог, порадниитво.

Received: 03 May 2019

Accepted: 24 May 2019 